\title{
Improved embryogenic callus induction and plant regeneration in big bluestem (Andropogon gerardii Vitman), a potential bioenergy feedstock
}

\author{
Pramod Pantha, Sathish Kumar Ponniah, Sixte Ntamatungiro and Muthusamy Manoharan*
}

Department of Agriculture, University of Arkansas at Pine Bluff, Pine Bluff, AR 71601, USA.

Received 25 June, 2016; Accepted 7 September, 2016

\begin{abstract}
The objective of this study was to develop an efficient regeneration protocol in big bluestem, a potential feedstock that produces huge biomass. Embryogenic calli were induced from the seeds of cultivars, Kaw and Earl, on Murashige and Skoog (MS) medium with different concentrations of 2,4dichlorophenoxyacetic acid (2,4-D) $\left(0.2,0.5,1.0,2.0,3.0\right.$ and $\left.5.0 \mathrm{mg} \mathrm{l}^{-1}\right)$ alone or in combination with 6benzylaminopurine (BA) $\left(0.5 \mathrm{mg} \mathrm{I}^{-1}\right)$ or L-proline $\left(2.0 \mathrm{~g} \mathrm{I}^{-1}\right)$. In Kaw, the highest number of embryogenic calli $(39.1 \%)$ was induced on MS $+0.5 \mathrm{mg} \mathrm{I}^{-1} 2,4-\mathrm{D}$ and L-proline, whereas in Earl, the highest number of embryogenic calli (39.8\%) was obtained on MS medium containing $1.0 \mathrm{mg} \mathrm{I}^{-1}$ 2,4-D and L-proline. The embryogenic calli were then transferred to regeneration media (MS medium supplemented with kinetin, $0.2,0.5,1.0,3.0$ and $5.0 \mathrm{mg} \mathrm{I}^{-1}$ or BA, 0.2, 0.5, 1.0, 3.0 and $5.0 \mathrm{mg} \mathrm{l}^{-1}$ ). Shoots were regenerated on all of the concentrations tested and the regeneration percentage and number of shoots per calli increased with the increase in BA or kinetin concentration. Regenerated shoots were transferred to half strength MS medium for rooting. The fully developed plantlets were established in the greenhouse. The regeneration protocol established in this study may be used for the application of genetic engineering technologies in big bluestem.
\end{abstract}

Key words: Big bluestem, biomass, embryogenic calli, L-proline, regeneration.

\section{INTRODUCTION}

Big bluestem (Andropogon gerardii Vitman) is a warmseason $\left(\mathrm{C}_{4}\right)$ perennial grass native to North America (Boe et al., 2004). It is adapted to most native prairie ecosystems and comprises as much as $80 \%$ of plant biomass in prairies in the North American Mid-western grassland (Gould and Shaw, 1983; Knapp et al., 1998). Compared to switchgrass (Panicum virgatum L.) and
Indiangrass (Sorghastrum nutans (L.) Nash), big bluestem produces twice the biomass due to its efficient nutrient utilization (Johnson and Matchett, 2001). Currently, big bluestem is considered a potential biomass feedstock for lignocellulosic ethanol production (Zhang et al., 2012). However, the biggest limiting factor in the efficient utilization of plant biomass for cellulosic bio-fuel is the

*Corresponding author. E-mail: manoharanm@uapb.edu. Tel: +01-870-575-8543. Fax: +01-870-575-4676.

Author(s) agree that this article remains permanently open access under the terms of the Creative Commons Attribution License 4.0 International License 
presence of the ligno-hemicellulose complex that prevent the enzyme cellulase from effective conversion of biomass to biofuel (Sticklen, 2008). While approaches such as acid or heat pre-treatment are being used to break the ligno-hemicellulosic complex, genetic engineering technology holds great promise for reducing lignin content in biomass through down-regulation of lignin pathway genes (Hisano et al., 2009). Such an approach requires an efficient plant regeneration system, which is not available for a number of important cultivars in big bluestem.

Despite its importance as a potential bioenergy grass, very few studies have been carried out on in vitro regeneration of big bluestem (Chen et al., 1977; Chen and Boe, 1988; Li et al., 2009a). Chen et al. (1977) and Chen and Boe (1988) regenerated plants from calli that were induced from young inflorescence on Linsmaier and Skoog (LS) medium supplemented with $5.0 \mathrm{mg} \mathrm{l}^{-1}$ of 2,4dichlorophenoxyacetic acid (2,4-D) and $0.2 \mathrm{mg} \mathrm{l}^{-1}$ kinetin. $\mathrm{Li}$ et al. (2009a) obtained embryogenic calli from mature seeds on LS medium containing 2.0 to $4.0 \mathrm{mg} \mathrm{l}^{-1}$ 2,4-D for big bluestem cultivars Bison and Bonilla. Cultivars such as Bison and Bonilla are well adapted to US Midwest and Western states; however, a regeneration system is not available for cultivars that are adapted to US Southern states such as Arkansas and Texas.

The objective of this study was, therefore, to establish an efficient regeneration system from the calli of mature seeds in big bluestem cultivars, Kaw and Earl, that are well adapted to the southern US. Mature seeds are considered an important source of explants, as they are readily available and used frequently for in vitro regeneration (Li et al., 2009a; Lee et al., 2006, 2008).

\section{MATERIALS AND METHODS}

\section{Plant materials}

Mature seeds of big bluestem grass cultivars, Kaw and Earl, were obtained from Turner Seeds, Breckenridge, TX, USA. The seeds were sterilized with $70 \%$ ethanol for 30 s, followed by $20 \%$ commercial bleach (sodium hypochlorite, 5.25\%) containing two drops of Tween 20 (MP Biomedicals, LLC, Aurora, Ohio, USA) for $45 \mathrm{~min}$, and then washed three times with sterile distilled water for 5 min each.

\section{Callus induction}

Sterilized seeds were cultured for callus induction on petri plates containing MS (Murashige and Skoog, 1962) medium supplemented with 2,4-dichlorophenoxyacetic acid (2,4-D) $(0.2,0.5,1.0,2.0,3.0$ and $5.0 \mathrm{mg} \mathrm{l}^{-1}$ ) alone or in combination with 6-benzylaminopurine (BA) $\left(0.5 \mathrm{mg} \mathrm{l}^{-1}\right)$ or L-proline $\left(2.0 \mathrm{~g} \mathrm{I}^{-1}\right)$. The components of MS medium as well as growth regulators, 2,4-D and BA were obtained from Sigma-Aldrich (St. Louis, MO, USA). L-Proline was obtained from Caisson Labs (Logan, UT, USA). Media were supplemented with $30 \mathrm{~g} \mathrm{I}^{-1}$ of sucrose (PhytoTechnology Laboratory, Shawnee Mission, KS, USA); $\mathrm{pH}$ was adjusted to 5.7 with $1 \mathrm{~N} \mathrm{NaOH}$ before sterilizing at $121^{\circ} \mathrm{C}(120 \mathrm{kPa}$ for $20 \mathrm{~min})$ and the media were solidified with $4.0 \mathrm{~g} \mathrm{I}^{-1}$ Gelzan (Phyto Technology Laboratory).
Callus induction was performed under dark at $28^{\circ} \mathrm{C}$ (Isotemp Incubator, Fisher Scientific, Hanover Park, IL, USA). Primary shoots from seed were removed 10 days after inoculation and subculture was done 3 weeks after inoculation on the same medium. Overall 18 treatments were tested for embryogenic callus induction in each cultivar. The frequency of embryogenic calli was calculated by: [the number of seeds producing embryogenic calli/the number of seeds germinated on callus induction medium] $\times 100$.

\section{Shoot regeneration, rooting, and plant establishment}

Embryogenic calli were transferred to regeneration medium for shoot regeneration. Regeneration media contained MS medium supplemented with kinetin $\left(0.2,0.5,1.0,3.0\right.$ and $5.0 \mathrm{mg} \mathrm{l}^{-1}$; SigmaAldrich) or BA $\left(0.2,0.5,1.0,3.0\right.$ and $\left.5.0 \mathrm{mg} \mathrm{l}^{-1}\right)$ and $30 \mathrm{~g} \mathrm{l}^{-1}$ of sucrose); $\mathrm{pH}$ was adjusted to 5.7 with $1 \mathrm{~N} \mathrm{NaOH}$ before sterilization and the media were solidified with $4.0 \mathrm{~g} \mathrm{l}^{-1}$ Gelzan. The cultures were incubated in a plant tissue culture chamber at $25^{\circ} \mathrm{C}$ under 16 h photoperiod (Percival Scientific, Perry, IA, USA).

After 4 weeks, the regenerated plants were transferred to rooting medium. Rooting medium contained half-strength MS medium with $30 \mathrm{~g} \mathrm{I}^{-1}$ of sucrose; $\mathrm{pH}$ was adjusted to 5.7 with $1 \mathrm{~N} \mathrm{NaOH}$ before sterilizing and the medium was solidified with $4.0 \mathrm{~g} \mathrm{l}^{-1}$ Gelzan. The rooting was carried out in a plant tissue culture chamber under a 16 h photoperiod at $25^{\circ} \mathrm{C}$ (Percival Scientific, Perry, IA, USA). Rooted plants, after 2 to 3 weeks, were transferred to peat pellets for 1 week for hardening and then to the greenhouse for further growth.

\section{Experimental design and statistical analysis}

The experiment was conducted in six replicates with 25 seeds per treatment and data presented here represent an average of six experiments. The experiment was performed as a completely randomized design. To assess the treatment effects, the percentages of primary calli, embryogenic calli and shoot regeneration were subjected to Analysis of Variance (ANOVA) and mean separation was performed using least significant difference (LSD) with SAS software, version 9.2 (SAS Institute Inc., 2008).

\section{RESULTS AND DISCUSSION}

\section{Seed germination}

Germination of mature seeds started 3 days after inoculation in both Kaw and Earl. Germination percentage ranged from 80.0 to 82.7 for Kaw and 60.3 to 75.3 for Earl (Table 1). Germination data were recorded 10 days after seed inoculation.

\section{Effect of 2,4-D on embryogenic calli induction}

Callus was initiated 7 days after inoculation of Kaw and 10 days after inoculation of Earl on MS medium containing different concentrations of 2,4-D. The callus thus formed was white and non-nodular (Figure 1a). After 3 weeks, callus was sub-cultured onto the same medium. After 1 week of subculture, nodular structures, which were smaller in size, light yellow, friable and fast-growing, started appearing on the outer surface of the calli. The 
Table 1. Effect of 2,4-dichlorophenoxyacetic acid (2,4-D), L-proline and 6-benzylaminopurine (BA) on embryogenic callus induction in big bluestem cv. Kaw and Earl.

\begin{tabular}{|c|c|c|c|c|c|c|}
\hline \multirow{2}{*}{ 2,4-D (mg l$\left.~^{-1}\right)$} & \multirow{2}{*}{ Proline $\left(\mathrm{g} \mathrm{I}^{-1}\right)$} & \multirow{2}{*}{$\mathrm{BA}\left(\mathrm{mg} \mathrm{l}^{-1}\right)$} & \multicolumn{2}{|c|}{$\%$ of seeds germinated ${ }^{1}$} & \multicolumn{2}{|c|}{$\%$ of embryogenic calli ${ }^{2}$} \\
\hline & & & Kaw & Earl & Kaw & Earl \\
\hline 0.2 & - & - & $82.0 \pm 6.1$ & $60.8 \pm 16.3$ & $9.8 \pm 3.4^{\mathrm{h}^{*}}$ & $10.1 \pm 3.9^{i^{*}}$ \\
\hline 0.5 & - & - & $81.3 \pm 9.7$ & $61.2 \pm 15.4$ & $13.2 \pm 4.3^{g, h}$ & $14.6 \pm 2.7^{\mathrm{g}, \mathrm{h}, \mathrm{i}}$ \\
\hline 1.0 & - & - & $80.0 \pm 14.1$ & $68.8 \pm 14.5$ & $14.2 \pm 2.8^{g, h}$ & $17.8 \pm 5.5^{\mathrm{e}, \mathrm{f}, \mathrm{g}, \mathrm{h}, \mathrm{i}}$ \\
\hline 2.0 & - & - & $80.1 \pm 12.8$ & $60.3 \pm 11.3$ & $18.6 \pm 5.6^{\mathrm{d}, \mathrm{e}, \mathrm{f}, \mathrm{g}}$ & $24.5 \pm 8.9^{\mathrm{c}, \mathrm{d}, \mathrm{e}, \mathrm{f}}$ \\
\hline 3.0 & - & - & $81.3 \pm 12.7$ & $64.8 \pm 10.9$ & $23.8 \pm 1.9^{\mathrm{c}, \mathrm{d}, \mathrm{e}}$ & $18.3 \pm 3.8^{\mathrm{e}, \mathrm{f}, \mathrm{g}, \mathrm{h}, \mathrm{i}}$ \\
\hline 5.0 & - & - & $80.7 \pm 11.1$ & $66.8 \pm 12.5$ & $18.8 \pm 2.7^{\mathrm{d}, \mathrm{e}, \mathrm{f}, \mathrm{g}}$ & $14.1 \pm 6.8^{\mathrm{h}, \mathrm{i}}$ \\
\hline 0.2 & 2.0 & - & $80.7 \pm 9.9$ & $67.3 \pm 8.5$ & $21.4 \pm 7.3^{\mathrm{c}, \mathrm{d}, \mathrm{e}, \mathrm{f}}$ & $15.1 \pm 6.6^{\mathrm{g}, \mathrm{h}, \mathrm{i}}$ \\
\hline 0.5 & 2.0 & - & $82.7 \pm 9.7$ & $68.0 \pm 13.6$ & $39.1 \pm 7.4^{a}$ & $30.7 \pm 9.9^{b, c}$ \\
\hline 1.0 & 2.0 & - & $82.0 \pm 9.7$ & $66.0 \pm 7.5$ & $31.0 \pm 8.6^{b}$ & $39.8 \pm 7.6^{a}$ \\
\hline 2.0 & 2.0 & - & $81.3 \pm 7.0$ & $72.0 \pm 9.1$ & $24.7 \pm 8.4^{\mathrm{b}, \mathrm{c}, \mathrm{d}}$ & $37.8 \pm 5.6^{\mathrm{a}, \mathrm{b}}$ \\
\hline 3.0 & 2.0 & - & $80.7 \pm 10.6$ & $73.3 \pm 6.5$ & $21.8 \pm 5.2^{\mathrm{c}, \mathrm{d}, \mathrm{e}, \mathrm{f}}$ & $26.0 \pm 7.4^{\mathrm{c}, \mathrm{d}, \mathrm{e}}$ \\
\hline 5.0 & 2.0 & - & $80.0 \pm 10.4$ & $71.3 \pm 15.1$ & $15.3 \pm 8.6^{\mathrm{f}, \mathrm{g}, \mathrm{h}}$ & $16.9 \pm 7.6^{\mathrm{f}, \mathrm{g}, \mathrm{h}, \mathrm{i}}$ \\
\hline 0.2 & - & 0.5 & $81.3 \pm 7.4$ & $68.7 \pm 6.9$ & $12.3 \pm 2.8^{\mathrm{g}, \mathrm{h}}$ & $13.8 \pm 7.1^{\mathrm{h}, \mathrm{i}}$ \\
\hline 0.5 & - & 0.5 & $80.0 \pm 6.7$ & $71.3 \pm 5.9$ & $15.9 \pm 6.6^{\mathrm{f}, \mathrm{g}, \mathrm{h}}$ & $20.7 \pm 4.6^{\mathrm{d}, \mathrm{e}, \mathrm{f}, \mathrm{g}, \mathrm{h}}$ \\
\hline 1.0 & - & 0.5 & $80.0 \pm 8.4$ & $75.3 \pm 7.3$ & $17.4 \pm 1.4^{\mathrm{e}, \mathrm{f}, \mathrm{g}}$ & $27.7 \pm 13.8^{\mathrm{c}, \mathrm{d}}$ \\
\hline 2.0 & - & 0.5 & $80.7 \pm 5.9$ & $72.0 \pm 5.1$ & $21.6 \pm 5.2^{\mathrm{c}, \mathrm{d}, \mathrm{e}, \mathrm{f}}$ & $23.0 \pm 6.4^{\mathrm{c}, \mathrm{d}, \mathrm{e}, \mathrm{f}, \mathrm{g}}$ \\
\hline 3.0 & - & 0.5 & $80.0 \pm 4.4$ & $70.6 \pm 5.5$ & $26.6 \pm 3.4^{b, c}$ & $20.9 \pm 8.6^{\mathrm{d}, \mathrm{e}, \mathrm{f}, \mathrm{g}, \mathrm{h}}$ \\
\hline 5.0 & - & 0.5 & $81.3 \pm 4.1$ & $70.0 \pm 6.1$ & $17.4 \pm 7.9^{\mathrm{e}, \mathrm{f}, \mathrm{g}}$ & $16.5 \pm 7.8^{\mathrm{f}, \mathrm{g}, \mathrm{h}, \mathrm{i}}$ \\
\hline
\end{tabular}

${ }^{1}$ Seed germination percentage was calculated based on the number of seeds germinated and the number of seeds inoculated. ${ }^{2}$ Percentage of embryogenic calli was determined based on the number of embryogenic calli formed and the number of seeds germinated. *Percentages followed by different superscript letters within a column are significantly different at $P \leq 0.05$. Each value represents the mean $\pm S D$ from six replicates.

fast growing nodular calli were recognized as embryogenic (Figure 1b), while the larger, white, slow growing non-nodular calli were identified as non-embryogenic (Figure 1a). The formation of two distinct calli, embryogenic and non-embryogenic, with different regeneration potential is an important characteristic of cereals and grasses (Pola et al., 2008). The auxin 2,4-D has been successfully used to induce embryogenic calli in grasses such as big bluestem (Chen et al., 1977; Chen and Boe, 1988; Li et al., 2009a), Indiangrass (Chen et al., 1979; Li et al., 2009b), Brachypodium (Zombori et al., 2011) and little bluestem (Schizachyrium scoparium (Michs.) Nash) (Songstad et al., 1986; Li et al., 2009a). In our study, $23.8 \%$ of germinated seed produced embryogenic calli on MS medium containing $3.0 \mathrm{mg} \mathrm{I}^{-1}$ $2,4-\mathrm{D}$ in Kaw and $24.5 \%$ of germinated seed produced embryogenic calli on MS medium with $2.0 \mathrm{mg} \mathrm{I}^{-1} 2,4-\mathrm{D}$ in Earl (Table 1). The percentage of embryogenic calli induced in our study is comparable to the percentage of embryogenic calli $(23.1 \%)$ obtained with the supplementation of 2,4-D in other big bluestem cultivars, Bison and Bonilla (Li et al., 2009a).

\section{Effect of L-proline on embryogenic calli induction}

The use of L-proline in the medium has a positive effect on the frequency of callus induction in rice (Oryza sativa L.), a member of grass family (Chowdhry et al., 1993; Ge et al., 2006). In this study, we have tested the effectiveness of L-proline $\left(2.0 \mathrm{~g} \mathrm{I}^{-1}\right)$ on embryogenic calli induction in Kaw and Earl (Table 1). With the addition of L-proline, the frequency of embryogenic calli was significantly increased to $39.1 \%$ on MS medium supplemented with $0.5 \mathrm{mg} \mathrm{I}^{-1} 2,4-\mathrm{D}$ in Kaw and $39.8 \%$ on MS medium containing $1.0 \mathrm{mg} \mathrm{l}^{-1} 2,4-\mathrm{D}$ in Earl. The percentage of germinated seed that produced embryogenic calli in this study $(39.1 \%$ in Kaw and $39.8 \%$ in Earl) was significantly higher (69 to $72 \%$ ) than the percentage of embryogenic calli obtained in big bluestem cultivars, Bison and Bonila (23.1\%) (Li et al., 2009a). Clearly, the increase in embryogenic calli frequency obtained in this study can be attributed to the supplementation of L-proline in callus induction medium. In switchgrass cv. Alamo, addition of L-proline increased the embryogenic calli formation efficiency by $30 \%$ ( $\mathrm{Li}$ and Qu, 2010). The effectiveness of L-proline for the initiation and maintenance of embryogenic calli has also been reported in rice (Datta et al., 1992; Kishor et al., 1999) and alfalfa (Medicago sativa L.) (Shetty and McKersie, 1993). L-Proline also promoted embryogenesis in somatic tissue cultures of Zea mays (Armstrong and Green, 1985; Vasil and Vasil, 1986) and wheat (Triticum aestivum L.) (Gill and Gosal, 2015). 

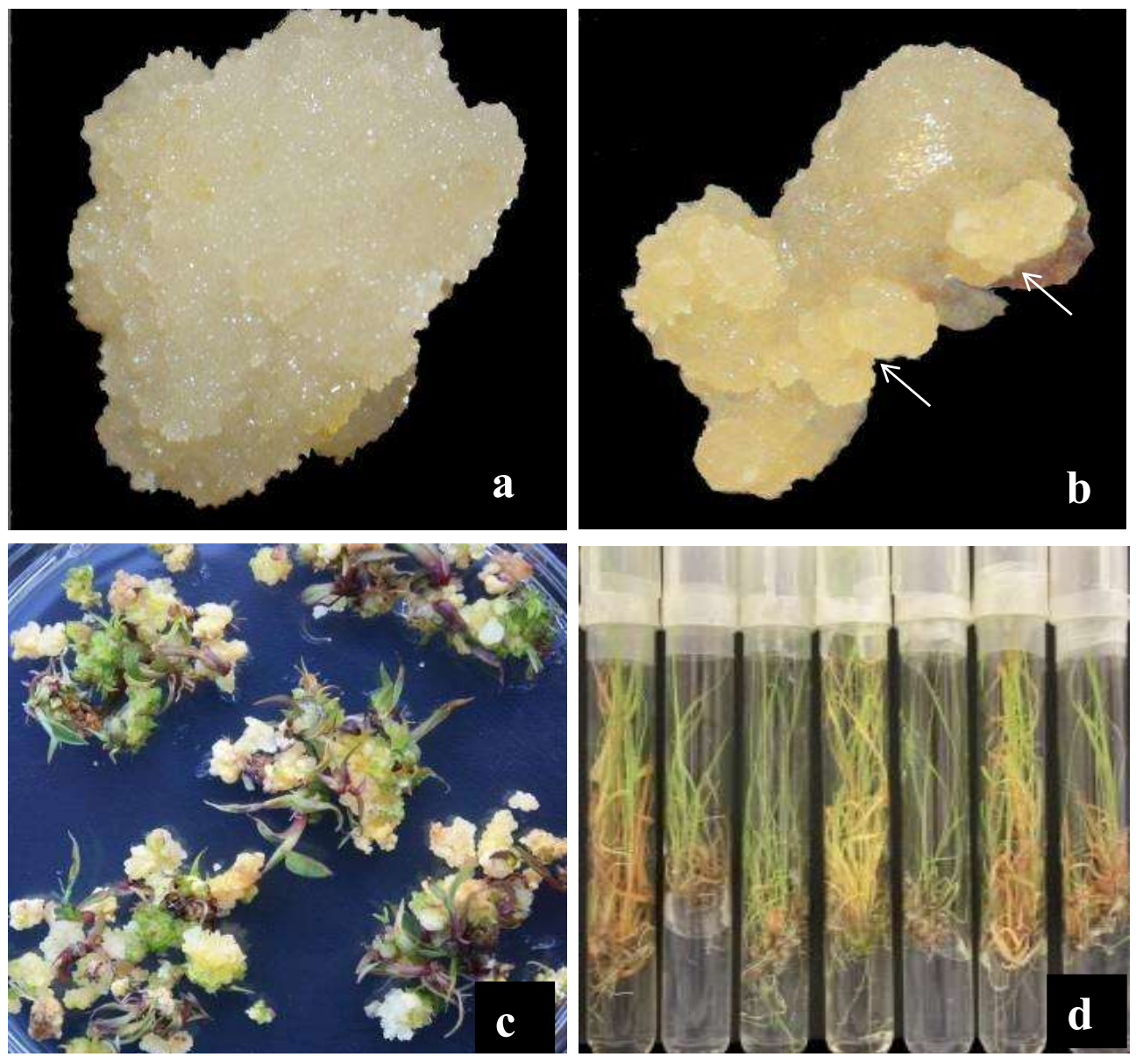

Figure 1. In vitro plant regeneration in big bluestem cv. Kaw: a. Non-embryogenic callus induced on MS + $3.0 \mathrm{mg} \mathrm{l}^{-1} 2,4-\mathrm{D}$ under dark at $28^{\circ} \mathrm{C}$; b. Embryogenic callus obtained on MS $+0.5 \mathrm{mg} \mathrm{I}^{-1}$ $2,4-\mathrm{D}+2.0 \mathrm{~g} \mathrm{I}^{-1} \mathrm{~L}$-proline under dark. Arrow indicates nodal embryogenic structures; C. Shoots regenerated from embryogenic calli 25 days after culture on regeneration medium (MS $+5.0 \mathrm{mg}$ $\mathrm{I}^{-1}$ kinetin) under light (16/8 $\mathrm{h}$ photoperiod); $\mathrm{d}$. Rooting of regenerated shoots on half strength MS medium under light (16/8 $\mathrm{h}$ photoperiod).

\section{Effect of BA on embryogenic calli induction}

In general, the addition of $0.5 \mathrm{mg} \mathrm{I}^{-1} \mathrm{BA}$ on MS medium supplemented with 2,4-D did not significantly increase embryogenic calli formation in Kaw and Earl (Table 1). In Kaw, the maximum of $26.6 \%$ embryogenic calli was obtained on MS medium containing $3.0 \mathrm{mg} \mathrm{I}^{-1}$ 2,4-D and $0.5 \mathrm{mg} \mathrm{l}^{-1} \mathrm{BA}$, while in Earl, the maximum of $27.7 \%$ embryogenic calli was formed on MS medium containing $1.0 \mathrm{mg} \mathrm{I}^{-1} 2,4-\mathrm{D}$ and $0.5 \mathrm{mg} \mathrm{I}^{-1}$ BA. It has been reported that $\mathrm{BA}$ in combination with auxins such as 2,4-D has a positive effect on callus induction in grasses (Altpeter and Posselt, 2000; Chaudhury and Qu, 2000; Bai and Qu, 2001). However, BA in combination with 2,4-D did not have a positive effect on callus induction in seashore paspalum turfgrass (Paspalum vaginatum Swartz) (Neibaur et al., 2008). The BA requirement may be species-specific (Chaudhury and Qu, 2000) and depends on the specific endogenous hormone levels (Bhaskaran and Smith, 1990).

\section{Shoot regeneration}

The actively growing embryogenic calli were transferred to MS medium with different concentrations of kinetin or BA for shoot induction. Addition of cytokinin in the regeneration medium can significantly increase plant regeneration in grasses (Songstad et al., 1986; Fei et al., 1997). In the present study, the percentage of the shoot regeneration and number of shoots per calli increased with the increasing concentrations of kinetin or BA in both Kaw and Earl (Table 2). However, compared to BA, kinetin was better with $100 \%$ regeneration achieved in both Kaw and Earl on MS medium containing $5.0 \mathrm{mg} \mathrm{l}^{-1}$ kinetin (Table 2) Similar high percentage of regeneration was observed with the addition of $5.0 \mathrm{mg} \mathrm{l}^{-1}$ kinetin in the regeneration medium for big bluestem cultivars, Bison 
Table 2. Effect of different concentrations of Kinetin or 6-benzylaminopurine (BA) on shoot regeneration from the embryogenic callus induced on MS medium in Kaw and Earl cultivars of big bluestem.

\begin{tabular}{cccccc}
\hline \multirow{2}{*}{ Kinetin $\left(\mathrm{mg} \mathrm{I}^{-1}\right)$} & \multirow{2}{*}{ BA $\left(\mathrm{mg} \mathrm{l}^{-1}\right)$} & \multicolumn{2}{c}{ \% of callus forming shoots } & \multicolumn{2}{c}{ Number of shoots per calli } \\
\cline { 3 - 6 } & & Kaw & Earl & Kaw & Earl \\
\hline 0.2 & - & $41.7 \pm 12.6^{\mathrm{e}, \mathrm{f}^{\mathrm{f}}}$ & $45.8 \pm 11.7^{\mathrm{e}, \mathrm{f}}$ & $2.9 \pm 0.5^{\mathrm{e}, \mathrm{f}}$ & $3.1 \pm 0.4^{\mathrm{e}, \mathrm{f}}$ \\
0.5 & - & $50.8 \pm 12.6^{\mathrm{d}, \mathrm{e}}$ & $60.0 \pm 14.1^{\mathrm{c}, \mathrm{d}}$ & $4.2 \pm 1.5^{\mathrm{c}, \mathrm{d}}$ & $4.6 \pm 0.7^{\mathrm{d}}$ \\
1.0 & - & $60.0 \pm 14.1^{\mathrm{c}, \mathrm{d}}$ & $69.1 \pm 14.2^{\mathrm{c}}$ & $5.2 \pm 2.4^{\mathrm{b}, \mathrm{c}}$ & $5.1 \pm 0.7^{\mathrm{c}, \mathrm{d}}$ \\
3.0 & - & $78.3 \pm 15.8^{\mathrm{b}}$ & $82.5 \pm 13.7^{\mathrm{b}}$ & $7.0 \pm 1.1^{\mathrm{a}}$ & $6.6 \pm 1.5^{\mathrm{b}}$ \\
5.0 & - & $100.0 \pm 0.0^{\mathrm{a}}$ & $100.0 \pm 0.0^{\mathrm{a}}$ & $7.4 \pm 0.9^{\mathrm{a}}$ & $8.2 \pm 0.9^{\mathrm{a}}$ \\
- & 0.2 & $23.4 \pm 11.2^{\mathrm{g}}$ & $23.3 \pm 11.2^{\mathrm{g}}$ & $2.6 \pm 0.5^{\mathrm{f}}$ & $2.4 \pm 0.5^{\mathrm{f}}$ \\
- & 0.5 & $32.5 \pm 11.0^{\mathrm{e}, \mathrm{f}, \mathrm{g}}$ & $36.7 \pm 3.9^{\mathrm{f}}$ & $3.5 \pm 1.1^{\mathrm{d}, \mathrm{e}, \mathrm{f}}$ & $4.1 \pm 1.4^{\mathrm{d}, \mathrm{e}}$ \\
- & 1.0 & $41.7 \pm 12.6^{\mathrm{e}, \mathrm{f}}$ & $50.8 \pm 12.6^{\mathrm{d}, \mathrm{e}}$ & $4.0 \pm 0.9^{\mathrm{d}, \mathrm{e}}$ & $5.2 \pm 0.8^{\mathrm{c}, \mathrm{d}}$ \\
- & 3.0 & $60.8 \pm 23.2^{\mathrm{c}, \mathrm{d}}$ & $69.2 \pm 14.2^{\mathrm{c}}$ & $5.5 \pm 1.4^{\mathrm{b}}$ & $5.9 \pm 0.9^{\mathrm{b}, \mathrm{c}}$ \\
- & 5.0 & $70.0 \pm 24.5^{\mathrm{b}, \mathrm{c}}$ & $83.4 \pm 19.2^{\mathrm{b}}$ & $5.7 \pm 1.2^{\mathrm{b}}$ & $6.6 \pm 1.3^{\mathrm{b}}$ \\
\hline
\end{tabular}

${ }^{2}$ Percentages and means with a different superscript letters within a column are significantly different at $P \leq 0.05$. Each value represents the percentages and means $\pm S D$ from four replicates.

and Bonila (Li et al., 2009a). Interestingly, only 70.0 and 83.4\% shoot regeneration was observed in Kaw and Earl, respectively, on MS medium containing $5.0 \mathrm{mg} \mathrm{I}^{-1} \mathrm{BA}$. An average of 7.4 shoots in Kaw and 8.2 shoots in Earl were regenerated on regeneration medium containing $5.0 \mathrm{mg} \mathrm{l}^{-}$ ${ }^{1}$ kinetin, while an average of 5.7 shoots in Kaw and 6.6 shoots in Earl were regenerated on MS with $5.0 \mathrm{mg} \mathrm{I}^{-1}$ BA.

\section{Rooting and plant establishment in greenhouse}

More than $90 \%$ of the regenerated shoots were successfully rooted on half strength MS without the addition of growth hormones. A similar percentage of rooting was achieved in big bluestem cultivars, Bison and Bonila (Li et al., 2009a). Fully rooted plants were transferred initially to peat pellets for hardening for one week and then to the greenhouse for further growth and development.

In conclusion, we have successfully established an improved regeneration system in two cultivars of big bluestem, Kaw and Earl, which are grown in the southern US. Both the cultivars showed enhanced embryogenic calli formation (39.1\% in Kaw and $39.8 \%$ in Earl) on MS medium containing 2,4-D and L-proline. In addition, shoots were successfully regenerated $(100 \%$ in Kaw and Earl) on MS medium containing kinetin $\left(5.0 \mathrm{mg} \mathrm{l}^{-1}\right)$. Because of high-frequency embryogenic calli formation and efficient plant regeneration, this protocol may be used for the application of genetic engineering technologies in big bluestem cultivars, Kaw and Earl.

\section{Conflict of Interests}

The authors have not declared any conflict of interests.

\section{ACKNOWLEDGEMENTS}

The author, Muthusamy Manoharan thank Dr. Lynn Dahleen, L\&Js Homegrown Exchange LLC, Albany, Wisconsin, for critical review of the manuscript and the Plant Powered Production (P3) Center, which was funded wholly or in part by the National Science Foundation (NSF) EPSCoR Program and the Arkansas Science and Technology Authority (ASTA) for providing funding support for this study. The NSF EPSCoR award number is: EPS-1003970.

\section{REFERENCES}

Altpeter F, Posselt UK (2000). Improved plant regeneration from cell suspensions of commercial cultivars, breeding and inbred lines of perennial ryegrass (Lolium perenne L.). J. Plant Physiol. 156:790796.

Armstrong CL, Green CE (1985). Establishment and maintenance of friable embryogenic maize callus and the involvement of L-proline. Planta 164:207-214.

Bai Y, Qu R (2001). Factors influencing tissue culture responses of mature seeds and immature embryos in turf-type tall fescue (Festuca arundinacea Schreb.). Plant Breed. 120:239-242.

Bhaskaran S, Smith RH (1990). Regeneration in cereal tissue culture: a review. Crop Sci. 30:1328-1336.

Boe A, Keeler K, Norrmann GA, Hatch SL (2004). The indigenous bluestems (Bothriochloa, Andropogon and Schizachyrium) of the western hemisphere and gamba grass Andropogon gayanus) In. Moser L, Byron B, Sollenberger L (eds) Warm-season (C4) grasses ASA, Madison, WI, Pp. 873-908.

Chaudhury A, Qu R (2000). Somatic embryogenesis and plant regeneration of turf-type bermudagrass: effect of 6-benzyladenine in callus induction medium. Plant Cell Tissue Organ Cult. 60:113-120.

Chen CH, Boe AA (1988). Big bluestem (Andropogon gerardii Vitman), little bluestem [Schizachyrium scoparium (Michs.) Nash] and indiangrass [Sorghastrum nutans (L.) Nash] In. Bajaj YPS (ed) Biotechnology in Agriculture and Forestry 6 Crops II, Springer-Verlag.

Chen CH, Lo PF, Ross JG (1979). Regeneration of plantlets from callus cultures of Indiangrass. Crop Sci. 19:117-118.

Chen $\mathrm{CH}$, Stenberg NE, Ross JG (1977). Clonal propagation of big 
bluestem by tissue culture. Crop Sci. 17:847-850.

Chowdhry CN, Tyagi AK, Maheshwari N, Maheshwari SC (1993). Effect of L-proline and L-tryptophan on somatic embryogenesis and plantlet regeneration of rice (Oryza sativa L. cv. Pusa 169) Plant Cell Tissue Organ Cult. 32:357-361.

Datta SK, Datta K, Soltanifar N, Donn G, Potrykus I (1992). Herbicide resistant indica rice plants from IRRI breeding line IRRI after PEG mediated transformation of protoplast. Plant Mol. Biol. 20:619-629.

Fei S, Read PE, Riordan T (1997). In Vitro regeneration of buffalograss through immature inflorescence culture. Int. Turfgrass Res. J. 8:283289.

Ge XJ, Chu ZH, Lin YJ, Wang SP (2006). A tissue culture system for different germplasms of indica rice. Plant Cell Rep. 25:392-402.

Gill AK, Gosal SS (2015). Improved somatic embryogenesis in Indian bread wheat (Triticum aestivum L.) cultivar HD 2967 through media manipulations. J. Cell Tissue Res. 15:4855-4860.

Gould FW, Shaw RB (1983). Grass systematics. 2nd (ed) College Station: Texas A\&M University Press.

Hisano H, Nandakumar R, Wang ZY (2009). Genetic modification of lignin biosynthesis for improved biofuel production. In Vitro Cell Dev. Biol. Plant 45:306-313.

Johnson LC, Matchett JR (2001). Fire and grazing regulate below ground processes in tallgrass prairie. Ecology 82:3377-3388.

Kishor PBK, Sangam S, Naidu KP (1999). Sodium, potassium, sugar, alcohol and proline mediated somatic embryogenesis and plant regeneration in recalcitrant rice callus. Plant Tissue Cult. Biotech.: Emerging Trends, Proc. Symposium, Hyderabad, India, Pp. 78-85.

Knapp AK, Briggs JM, Blair JM, Turner CL (1998). Patterns and controls of aboveground net primary production in tallgrass prairie. In. Knapp AK, Briggs JM, Harnett DC, Collins SL (eds) Grassland dynamics: Long-term ecological research in tallgrass prairie. Oxford University Press, New York pp. 193-221.

Lee KW, Ahsan N, Lee SH, Lee DG, Kim KH, Alam I, Kwon SY, Kim JS, Back K, Lee SS, Lee BH (2008). Responses of MxPPO overexpressing transgenic tall fescue plants to two diphenyl-ether herbicides, oxyfluorfen and acifluorfen. Acta Physiol. Plant. 30:745754.

Lee SH, Lee DG, Woo HS, Lee KW, Kim DH, Kwak SS, Kim JS, Kim, HG, Ahsan N, Choi MS, Yang JK, Lee BH (2006). Production of transgenic orchardgrass via Agrobacterium-mediated transformation of seed-derived callus tissues. Plant Sci. 171:408-414.
Li R, Qu R (2010). High throughput Agrobacterium-mediated switchgrass transformation. Biomass Bioenergy 35:1046-1054.

Li Y, Gao J, Fei SZ (2009a). High frequency embryogenic callus induction and plant regeneration from mature caryopsis of big bluestem and little bluestem. Sci. Hortic. 121:348-352.

Li Y, Gao J, Fei SZ (2009b). High frequency in vitro embryogenic callus induction and plant regeneration from Indiangrass mature caryopsis. Sci. Hortic. 119:306-309.

Murashige T, Skoog $F$ (1962). A revised medium for rapid growth and bioassays with tobacco tissue cultures. Physiol. Plant 15:473-497.

Neibaur I, Gallo M, Altpeter F (2008). The effect of auxin type and cytokinin concentration on callus induction and plant regeneration frequency from immature inflorescence segments of seashore paspalum (Paspalum vaginatum Swartz). In Vitro Cell Dev. Biol. Plant 44:480-486.

Pola S, Mani NS, Ramana T (2008). Plant tissue culture studies in sorghum bicolor: immature embryo explants as the source material. Intl. J. Plant Prod. 2:1-14.

SAS Institute Inc. (2008). SAS Software version 9.2. SAS Institute, Cary, NC

Shetty K, McKersie BD (1993). Proline, thioproline and potassium mediated stimulation of somatic embryogenesis in alfalfa (Medicago sativa L.). Plant Sci. 88:185-193.

Songstad DD, Chen CH, Boe AA (1986). Plant regeneration in callus cultures derived from young inflorescences of little bluestem. Crop Sci. 26:827-829.

Sticklen MB (2008). Plant genetic engineering for biofuel production: towards affordable cellulosic ethanol. Nat. Rev. Genet. 9:433-443.

Vasil V, Vasil IK (1986). Plant regeneration from friable embryogenic callus and cell suspension cultures of Zea mays L. J. Plant Physiol. 124:399-408.

Zhang K, Johnson L, Nelson R, Yuan W, Pei Z, Wang D (2012). Chemical and elemental composition of big bluestem as affected by ecotype and planting location along the precipitation gradient of the great plains. Ind. Crop Prod. 40:210-218.

Zombori Z, Szécsényi M, Györgyey J (2011). Different approaches for Agrobacterium-mediated genetic transformation of Brachypodium distachyon, a new model plant for temperate grasses. Acta Biol. Szeged. 55:193-195. 